総説品

\title{
乾燥装置の選 定*
}

桐栄良 三**

\section{1. 選定の基礪}

工業的炕乾煤を考える場合には，まずつぎの二項を充

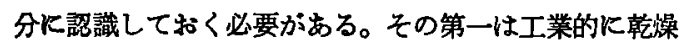
を行う意味は暲燥に要する経費を最小に抑えることに他 ならない。乾嬠汳応装置とか，蒸留，吸収あるいは粉 碎、分離などの操作と異なり、ほとんど材料は汪ってお いてる製品となりらるるのである。したがって工業的に

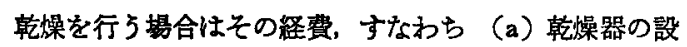
備費（付属設㣁を含む）と（b）運転費（然料費, 動力 費，人件費および乾燥のための材料の蓄積に対して要す る費用)の和を最低にするよ5な乾燥法が最も適してい るということになる。したがってある場合には天日勃㰒 が他のあらゆる人工乾燥化まさって最適であるといらこ とるありらる訳である。

第二には乾燥器には万能のものはありえないといらこ とである。乾燥の対象となる材料は木材々䒼，衙生陶器 のよらな大きな一定の形をした材料から，布紙状材料， 短栱維材料，フレーク材料，熄，粒，粉状材料さらには 糊泥状材料，泥永，液状材料と全く千差万別であり，こ れらを一律の乾燥器で扱うことは全く不可能である。た。 とえば蒸溜とか吸收の場合のように，棚段塔とか充填塔 を用いればよいといらのではなく，ほとんどあらゆる形 热の固体から液体まです処理するために，各種材料に対 する乾燥装置の選定が重要な問題である。与兄られた材 料にしたがって最適の乾燥装直を選ばねばならない。あ る種の材料火は最適の装置であってわ，他の材料に対し ては全く不適当であるという乾嬠器が多い。

\section{2. 選定の方法}

a. 乾嬠前の眖水 1 でのべた 2 項目を根本として 畉の選定にはいる訳であるが，その前に乾燥前機械 的脱水操作を受けるものについては，これ関して今一 度の検討を加える必要がある。乾燥により I kg の水分を 蒸発さすためには理論的に䄪 $600 \mathrm{kcal}$ の熱量を要し, これに乾煤効率などを孝えるとさらに多くの熱量を要す る。今これを機械的脱水化要する経費と比較すると，多 くの場合後者の方が遥か炕安価であり,できる限り機械

\footnotetext{
* 昭和 33 年 3 月 8 日受理

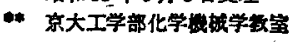

的脱水により含水率の低下をはかることが望まれる。湖 過器および遠心脱水器の進歩近年特に著るしいるのが ありこれらを用いて㖁燥沉かる材料の含水率を著る。 しく低下させ克た例も多い。

b. 湿潣時材料状龍 乾燥装置の選定に当り, ます 第一飞考えることは，材料の湿潤時状態対して，それ に適応した彰燥器を選らことである。この選定を誤ると たとえその乾燥器そのるのは合理的に設計されていてる 選択の正しい乾燥器に較へると綕合経費で格段の開きが 生じてくる。各種材料状態に対する適応乾燥器を乾嬠装， 膡選定表 I. Кあげてある。

c. 処理量と前処理方式 同一湿潤時材料形態の6 のでるその処理量の多宾により乾燥方式を変える必要が あり，また連続方式によるか，回分方式によるか炕よっ ても適応乾燥器が变る場合が多い。

乾燥の方式としては大量連続, 小量連続，大量回分打 上び小量回分の 4 方式がある。連続または回分は乾燥器 の特性によるが，さらに乾燥の前後の操作が連続か回分 かにる考虑を払 5 要がある。これらの場合についてはb。 と同しく選定表 I. に分類してある。

d. 材料特性 つきに材料の特性に基いてさらに最 適乾燥器の検討を進める。すなわち熱的性質, 粘着性, 毒性，粒子径，含水率，粒子破壊特よびダスティング等 々に関して考虑を厸い，適応乾燥器中で最適乾燥器を選 定する。この場合特殊の材料では適応度の高いAクラス のものが選定できなくて， B クラスのるのに限られる場 合がある。これらについては乾燥装置特性表 II を参考不。 して選定すればよい。

e. 工場条件 さらにその工場独特の条件を有する るのはそれを付加して決めねばならぬ。これは主として 熱源の問題であるが，廃ガスなど比較的安価にある種の 熱源がえられる場合については，熱量費が低廉になるた， めたと党て材料比しては適応度が B クラスるしく は C クラスのもので，熱效率が悪いとか設備費が禽む゙ ような場合です総合経費として有利な場合がある。この 場合る乾燥装置特性表 II を参考飞して決めればよい。

すなわちまつ b. c. の条件により雗燥装咱定表 Iか ら適応乾煤器を選び, さらにd. e. の条件から乾燥装展 特性表 II を参考して最適乾燥器を决定すれに゙よい。 
乾 燥 淩 置

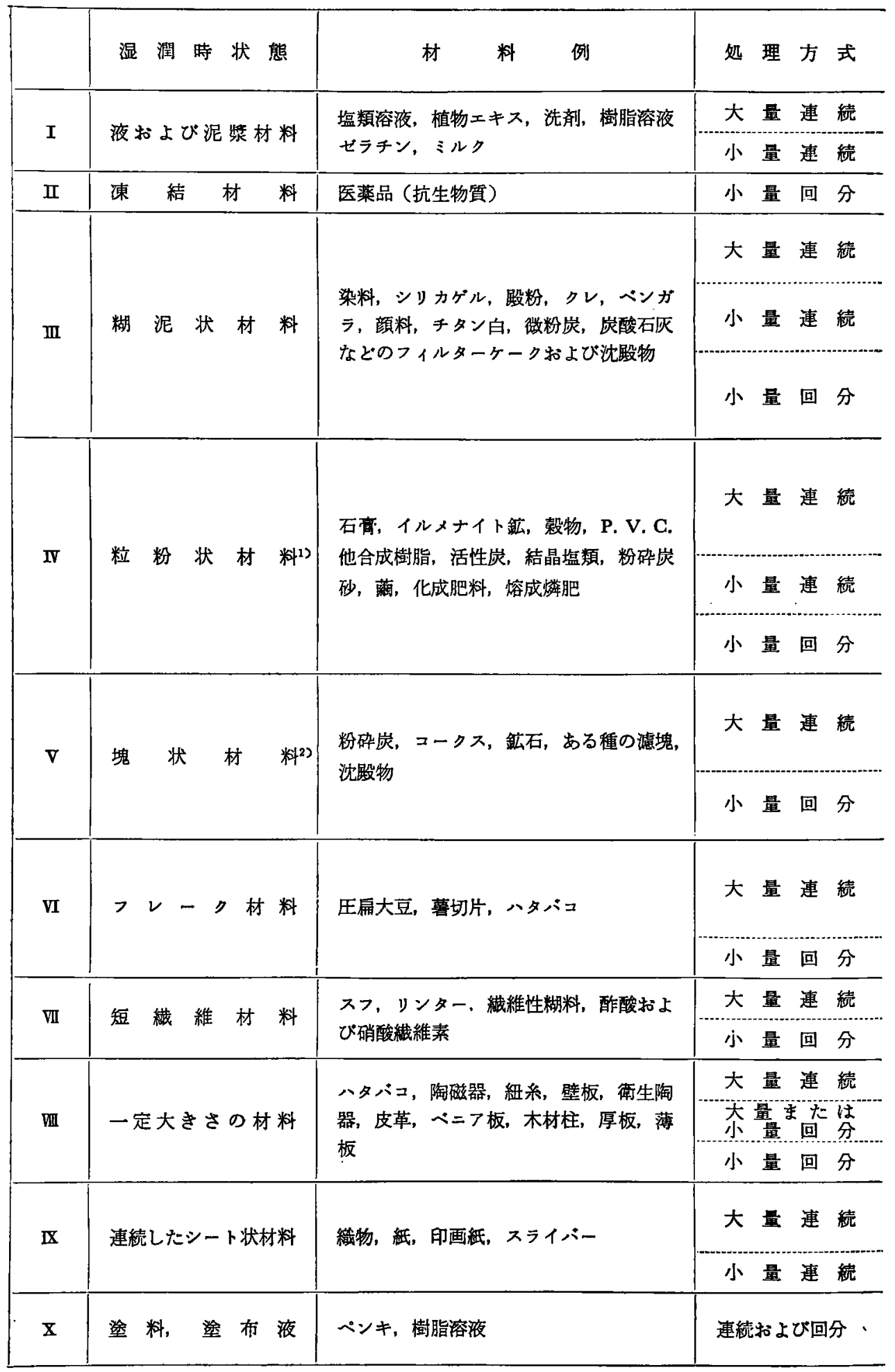

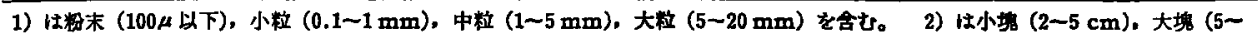




\section{選定表 1}

\begin{tabular}{|c|c|c|}
\hline 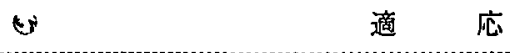 & 燥 & \\
\hline $\mathbf{A}$ & B & $\mathrm{C}$ \\
\hline \multirow{2}{*}{\multicolumn{3}{|c|}{$\begin{array}{l}\text { a. 噴 雾 } \\
\text { a. } ト \text { トラム (真空ドラム) }\end{array}$}} \\
\hline & & \\
\hline \multicolumn{3}{|l|}{ a. 凍 結 } \\
\hline $\begin{array}{l}\text { a. 気 流 } \\
\text { b. 通気パンド(トンネル) }\end{array}$ & $\begin{array}{l}\text { c. 並行流トンネル } \\
\text { d. 噴蓩 }\end{array}$ & \\
\hline \multicolumn{3}{|l|}{$\begin{array}{l}\text { e. 伝導受熱円筒および溝型擋拌 } \\
\text { g. ドラム(真空ドラム) }\end{array}$} \\
\hline $\begin{array}{l}\text { e. 伝道受熱円筒および溝型擋拌（真空 } \\
\text { 含む） } \\
\text { h. 通気箱型 }\end{array}$ & $\begin{array}{l}\text { i. 並行流箱型 } \\
\text { j. 真空箱型 }\end{array}$ & f. 平板撹拌 \\
\hline $\begin{array}{llll}\text { a. } & \text { 気 流 } & \text { b. } & \text { 熱風受熱溝型撹拌 } \\
\text { c. } & \text { 回 転 } & \text { d. } & \text { 水蒸気加熱管付回転 } \\
\text { e. } & \text { 流動層 } & & \\
\text { f. } & \text { 通気回転および通気堅型 }\end{array}$ & $\begin{array}{l}\text { g. 通気ハンド (トンネル) } \\
\text { h. 多重段円盤 } \\
\text { i. ターボ堅型および堅型 }\end{array}$ & j. 並行流トンネル \\
\hline \multicolumn{3}{|l|}{ k. 层導受熱円筒および溝型擋拌 } \\
\hline $\begin{array}{l}\text { k. 伝導受熱円筒および溝型擋拌（真空 } \\
\text { を含も） }\end{array}$ & $\begin{array}{l}\text { 1. 通気箱型 } \\
\text { n. 真空箱型 }\end{array}$ & m. 並行流箱型 \\
\hline \multirow[t]{2}{*}{$\begin{array}{l}\text { a. 回 転 } \\
\text { b. 通気回転および通気竪型 } \\
\text { c. 水蒸気加坴管付回転 }\end{array}$} & $\begin{array}{l}\text { d. 並行流トンネル(ハンン } \\
\text { e. 通気ハンド(トンネル) }\end{array}$ & \\
\hline & $\begin{array}{l}\text { f. 並行流箱型 } \\
\text { g. 通気箱型 }\end{array}$ & \\
\hline $\begin{array}{l}\text { a. 通気バンド } \\
\text { b. 水蒸気加熱管付回転 } \\
\text { c. 通気回転 }\end{array}$ & & d. 並行流ベンド(ト \\
\hline e. 通気箱型 & & f. 並行流箱型 \\
\hline \multicolumn{3}{|l|}{ a. 通気パンド } \\
\hline \multicolumn{3}{|l|}{ b. 通気箱型 } \\
\hline a. 並行流トンネル（パンド） & c. 通気トソネル (パンド) & \\
\hline \multirow[t]{2}{*}{ b. 並行流箱型 } & e. 高周波 & \\
\hline & d. 通気箱型 & \\
\hline \multicolumn{3}{|l|}{$\begin{array}{l}\text { a. 並行流または直角流シート用 } \\
\text { b. 多円筒 }\end{array}$} \\
\hline c. 単一ないし数円筒 & d. 赤外線 & \\
\hline $\begin{array}{l}\text { a. 赤外線 } \\
\text { b. 並行流または直角流トンネル（箱型） }\end{array}$ & & \\
\hline
\end{tabular}

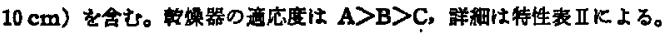




\section{乾蜗装置特性表 II}

\section{特性表 II の各欄説明表}

（1）連続大量：連続小量：回分大量：回分小量の 区別

(2) 乾燥器の適応度 : A > B >C一般にはA上り 選ふ。特殊な材料の時にはBによることが岕 る。特別な理由なくしてはCは避けた方がよ $\omega_{0}$

（3）設備费：設備費の安価な順に A，B，C とす る。

（4）熱効率：40\%以下 C，40 60\% B，60 80 \% Aとする。

（5）連続大量の場合には経済的な最低処理量を示 し，それ以上の処理量なら経済的であるとい 弓意味。小量の場合には 1 基での処理の最大 限界量。

（6）泍続大量の場合は現在使用されている最大処 理量。

（7）乾燥時間：一般炕常用される乾燥時間を示 す。

（8）処理限界：例えば粘度，粒径，粘着性なと。

（9）装置についての注意, 付属設備, 製品形状な そ。

\section{I．液および泥墏材料}

\section{a. 嫩篛乾燥器}
(1) 連大
(2) A
(3) $\mathrm{B}$ (4) $\mathrm{A}\left(300^{\circ} \mathrm{C}\right.$ 以上)
B $\left(300^{\circ} \mathrm{C}\right.$ 以下)
(5) $100 \mathrm{~kg}$-水/ $/ \mathrm{hr} \quad$ (6) 2000
$\mathrm{kg} / \mathrm{hr} \quad$ (7) $5 \sim 40 \mathrm{sec} \quad$ （8）粘度 $10^{4}$ c. p. まで
（9）球形中空粒 $10 \sim 500 \mu$ ，容積密度小

b. ドラム (真空ドラム) 颙燥器

(1) 連小 (2) A (3) B (4) A (5) $200 \mathrm{~kg}$ 水 $/ \mathrm{hr}$ （7）10〜90 sec（8）温度制限または溶剮 のときは真空 (9) 粉状またはフレーク状製品,

ドラムに均一薄膜に付着させることに注意

\section{II. 凍 結 材 料}

\section{a. 凍結乾燥器}

(1) 回小 (2) A (3) C (4) C (7) 6 24 $\mathrm{hr}$ （8）層厚み 2 3 cm で（9）海綿状または 粉状製品, 高真空 $\left(10^{-1} \sim 10^{-3} \mathrm{mmHg}\right)$ 設䜤費大

\section{III. 糊 泥状材料}

a. 気流乾燥器

（1）速大（2）A (3) A (4) A (常用 300 $600^{\circ} \mathrm{C}$ ) (5) $100 \mathrm{~kg}$-水 $/ \mathrm{hr}^{\prime}$ (6) $1000 \mathrm{~kg} / \mathrm{hr}^{\prime}$ (7) 1 $\sim 8 \mathrm{sec}$ （8）粘着性の比較的弱い材料（9）解 砕機要, 材料供給江注意

b. 通気バンド (トンネル) 乾燥器

(1) 連大 (2) A (3) B (4) B (5) $200 \mathrm{~kg}-$ 水 $/ \mathrm{hr}$ （6） $2 \mathrm{t}$-水 $/ \mathrm{hr}$ （7）20 50 min （8）只

ドンまたは角片状に整形できてその形を保つるの （9）翰燥後解碎必要

c. 並行流トンネル乾燥器

(1) 連大 (2) B (3) A (4) C (7) $4 \sim 24$ hr（8）他の乾燥法の適用できぬ場合（9）熱風 の偏流注意

d. 噴蓩乾燥器

（1）連大（2）B（8）加熱汇上り泥漿化する るののみ。他はＩa.K同じ。ズル磨耗注意

e. 伝導受熱円筒就よび瑇型摚拌乾燥器

(1) 連小 (2) A (3) A (4) A (5) $200 \mathrm{~kg} /$ $\mathrm{hr}$ （7） $0.5 \sim 2 \mathrm{hr}$ (8) 乾燥中餅状を呈する。の 不可。乾嬠末期滥微粉をずる（9）小粒子を形 成することあり。

（1）回小（2）A（5） $2 \mathrm{t}$ （7） $\mathrm{l} \sim 8 \mathrm{hr}$ （9）真空 方式が用いられる。自働排出可，他は連続と同じ

f. 平板擋拌型乾燥器

(1) 回小 (2) C (3) A (4) A (5) $300 \mathrm{~kg}$

（7） $1 \sim 8 \mathrm{hr}$ 他はIII e と同し。

g. ドラム（真空ドラム）乾燥器

（1）連小 (2) A （3）B (4) A （9）均一厚

みにローラーで王着すること。加熱擋拌により泥 漿化するるのはI b. に同じ。他はI b.に同じ

h. 通気箱型乾燥器

（1）回小（2）A（3）A（9）材料層のみを均 一江熱風通過注意。他は III b. 江同し。

i. 並行流箱型乾燥器

（1）回小 (2) B (3) A （4）C（B）他の方 法の適用でき女揚合（9）䓡風が偏流を起さない 上万注意

\section{j. 真空箱型乾燥器}

(1) 回小 (2) B (3) C (4) B (5) $400 \mathrm{~kg}$ （8）材料特性（温度制限，性など）または溶刘 の場合 (9）各段の均一排気䄮よび加熱注意 


\section{IV. 粒粉状材料}

\section{... 気流乾燥器}

（1）連大 (2) A (3) A (4) A (常用 300 $\left.600^{\circ} \mathrm{C}\right), \mathrm{B}\left(300^{\circ} \mathrm{C}\right.$ 以下) (5) $100 \mathrm{~kg}$-水 $/ \mathrm{hr}$ たは $1 \mathrm{t} / \mathrm{hr}$ （6） $2 \mathrm{t}$-水/hrまたは $15 \mathrm{t} / \mathrm{hr}$ （7） 1 $\sim 10 \mathrm{sec}$ （8）粘着材料不適，製品含水率 $0.3 \%$ 以下なら粒径 $2 \mathrm{~mm}$ 以下（9）水分による凝集性 大なすのは解砕機または叨解機要。他は直接供給。 少しの材料破壊がある。

b. 空気受熱溝型擋拌彰燥器

（1）連大 (2) A (3) A (4) A (5) $200 \mathrm{~kg}$ 水/hr たな $2 \mathrm{t} / \mathrm{hr}$ (6) $4 \mathrm{t}$-水/hr または $15 \mathrm{t} / \mathrm{hr}$ （7） $4 \sim 20 \mathrm{sec}$ (8) 粘着材料不適，可成材料破塄 あり。小粒以上の粒子 $40 \mathrm{~mm}$ まで可。

c. 回転漧燥器 (単円筒直接, 二重円筒複合または 間接加熱)

(1) 連大 (2) A (3) B (4) B (5) $1 \mathrm{t} / \mathrm{hr}$ (6) $15 \mathrm{t} / \mathrm{hr}$ (7) $10 \sim 40 \mathrm{~min}$ (8) $200 \mu$ 以上の 粒子に適。凝集性の強い材料(例えば砂で 18\%以 上) 不可 (9) $100 \mu$ 程度は間接加熱。少しの粒 子破壊あり

\section{d. 水蒸気加熱管付回転乾燥器}

(1) 連大 (2) A (3) B (4) A (5) $2 \mathrm{t} / \mathrm{hr}$ (6) $15 \mathrm{t} / \mathrm{hr}$ (7) $10 \sim 40 \mathrm{~min}$ (8) $100 \mathrm{~s}$ 程度以 上の粒子。加熱管光粘着のるの不可（9）自然通 風でダスティング小

\section{e. 流動層乾燥器}

（1）連大 (2) A (3) A (4) A (5) $100 \mathrm{~kg}$ 水/ $/ \mathrm{hr}$ または $200 \mathrm{~kg} / \mathrm{hr}$ （6） $15 \mathrm{t} / \mathrm{hr}$ （7） $10 \mathrm{sec}$ $\sim 6 \min$ (8) $500 \mu$ 以上飞適。気流乾燥々接続使 用, 凝集性の強い材料不可（9）向流操作である が顕整回収可能

f. 通気回転および通気㹂型乾燥器

(1) 連大 (2) A (3) B (4) B (5) $1 \mathrm{t} / \mathrm{hr}$ (7) $5 \sim 30 \mathrm{~min}$ (8) $200 \mu$ 以上の粒子, 凝集性大 なもの不可 (9) 粒子破壊少。わが国での使用例 少し

\section{g. 通気バンド (トンネル) 乾燥器}

(1) 連大 (2) B (3) B (4) B (5) $200 \mathrm{~kg}$ 水 $/ \mathrm{hr}$ （6） $6 \mathrm{t} / \mathrm{hr}$ （7） $5 \sim 40 \mathrm{~min}$ （8） $400 \mu$ 以 上の粒子火適用。最高温度 $250^{\circ} \mathrm{C}$, 粒子全く破壊 されず。材料層のみ熱風が均一に通過するように 注意。

h. 多重段円盤晥燥器

(1) 連大 (2) B (3) C (4) B (5) $100 \mathrm{~kg}$ 办 $/ \mathrm{hr}$ または $300 \mathrm{~kg} / \mathrm{hr}$ （6） $3 \mathrm{t} / \mathrm{hr}$ （7） $30 \mathrm{~min}$ $\sim 4 \mathrm{hr}$ （8）凝集性大なものに不適。構造複雑。 （9）ダスティンダ少。床面樻小。 i. ターボ㹂型括よび堅型乾嬠器

(1) 連大 (2) B (3) B (4) B (5) $100 \mathrm{~kg}$ 水 $/ \mathrm{hr}$ (6) $15 \mathrm{t} / \mathrm{hr}$ (7) $10 \mathrm{~min} \sim 3 \mathrm{hr}$ (8) 凝 集性大きいもの不適（9）ダスティンダ小。棚の 移動するるのでは全くなし。床面積小。

j. 並行流トンネル (パンド) 乾燥器

(1) 連小（2） C (3) A （4） C （7） $4 \sim 24$ hr 他は IIIc.に同じ。

k. 伝導受熱円筒及び溝型擋拌乾燥器

(1) 連小 （2） A （3） A (4) A （5） $1 \mathrm{t} / \mathrm{hr}$ （6） $5 \sim 30 \mathrm{~min}$ 特に水分多いるの $2 \mathrm{hr}$ （8）粒子 が幾分破㣀を受ける。乾燥末期に幾分ダスティン グあり（9）小粒子形成の場合あり

(1) 回小 (2) A (3) A (4) A (5) $2 \mathrm{t}$ (7)

$0.5 \sim 8 \mathrm{hr}$ （9）真空方式可。自働排出可能

1. 通気箱型乾燥器

（1）回小（2）B （3） A （4）C 他は IV g. に同じ

m. 並行流箱型乾嬠器

(1) 回小 (2) C (3) A (4) C 他は III c. 洞じ。

n. 真空箱型乾燥器

(1) 回小 (2) B (3) C (4) B (8) 温度制 限または溶蝺回収の場合。他は IV j. に同し

\section{V. 塊状材料}

a. 回転乾燥器（值接加熱単筒または複合加熱二重 简式)

(1) 連大 (2) A (3) B (4) B (5) $3 \mathrm{t} / \mathrm{hr}$

(6) $20 \mathrm{t} / \mathrm{hr}$ (7) $5 \sim 20 \mathrm{~min}$

b. 通気回転拉よび通気㹂型乾燥器

(1) 重大 (2) A (3) B (4) B (7) $5 \sim 20$ min 他は IV f.K同じ

c. 水蒸気加熱管付回転乾燥器

(1) 連大 (2) A (3) B (4) A (7) $5 \sim 20$ min（8）小塊飞適す。他は IV d. に同じ

d. 並行流トンネル (パンド) 乾嬠器

（1）連大 （2）B （3）A（4）C（8）塊をを のまま乾嬠する場合のみ

e. 通気バンド (トンネル) 乾燥器

（1）連大 （2）B (3) B （4）C （8）塊をそ のまま乾燥する場合のみ

f. 並行流箱型乾燥器

（1）回小（2）B 他は III c. K同じ

g. 通気箱型乾燥器

（1）回小（2）B 他は IV g.K同し。 


\section{VI. フレーク材料}

\section{a. 通気パンド乾燥器}

(1) 連大 (2) A (3) B (4) B (5) $2 \mathrm{t} / \mathrm{hr}$ (6) $10 \mathrm{t} / \mathrm{hr}$ （7） $10 \sim 30 \mathrm{~min}$ （8）層厚み $10 \sim$ $30 \mathrm{~cm}$ （9）材料破壊全くなし。熱風が噃のみを 均一に通過するよう注意

b. 水蒸気管付回転乾燥器

(1) 連大 (2) A (3) B (4) A (5) $2 \mathrm{t} / \mathrm{hr}$ (6) $10 \mathrm{t} / \mathrm{hr}$ (7) $10 \sim 30 \mathrm{~min}$ (8) 材料方程度 破買される。粘着性材料不適（9）ダスティンダ 小

\section{c. 通気回転乾燥器}
（1）連大 (2) A (3) B (4) B (5) $1 \mathrm{t} / \mathrm{hr}$

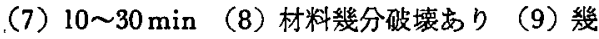
分ダスティングあり。わが国では例少し

d. 並行流トンネル (パンド) 乾蜗器
(1) 連大 (2) $\mathrm{C}$
(3) $\mathrm{A}$
（4）B VI a. の適用 できない場合のみ

c. 通気箱型草燥器
(1) 回小
(2) A (3) A
(4) C (5) $3 \mathrm{~m}^{3}-$ 材
料。他はV a.に同し

f. 並行流箱型乾燥器
(1) 回小 (2) C
（3） A （4）C 他はIII c. に同じ

\section{VII. 短 織 維 材 料}

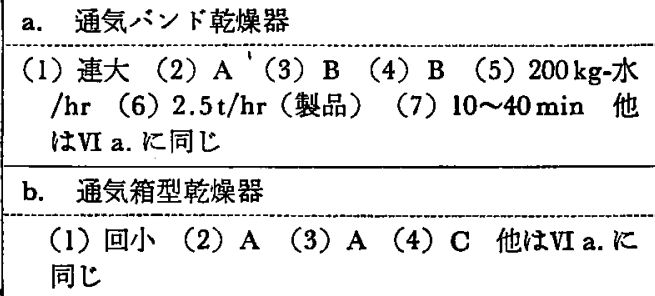

\section{VIII. 一定大きさの材料}

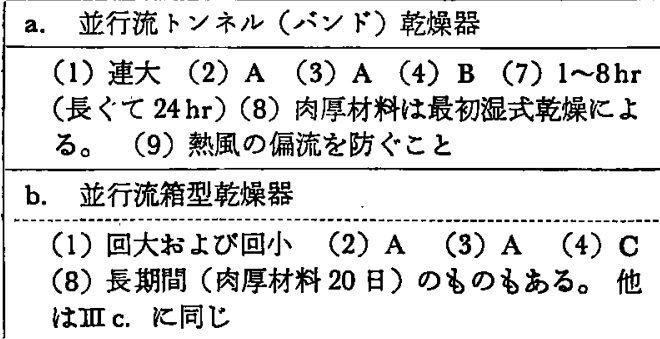

\section{c. 通気トンネル (パンド) 乾燥器}

(1) 連大 (2) B (3) B (4) B (7) $1 \sim 8 \mathrm{hr}$ 他は VII a. K同し

d. 通気箱型乾燥器
(1) 回小
(2) $\mathrm{B}$
(3) $\mathbf{A}$
（4） C 他はIV g 同じ

c. 高周波乾燥器

(1) 回大および回小 (2) B (3) B (4) C (8) 木材柱および厚板，スポンジゴムの乾燥就よ び合板の接着などに限定。厚板では最初湿式乾燥 による。

\section{IX. 連続したシート状材料}

\section{a. 並行流または直角流シート用畭燥器}

（1）連大 (2) A (3) A, B (4) C （7） 1 $30 \mathrm{~min}$ （8）ループ式，テンター式，塔式など種 々の形式がある。（9）シートを通気乾燥するこ とがあり，直角流はノズルからの吹出しが多い

b. 多円筒乾燥器

(1) 連大 (2) A (3) C (4) A (7) $0.5 \sim 3$ min 材料移動速度 $30 \sim 40 \mathrm{~m} / \mathrm{min}$ （9）熱風併 用が多い

c. 単一ないし数円筒乾知器

（1）連小 (2) A （3） A （4） A (7) $10 \sim 30$ sec 他は区 b K同じ

d. 赤外線乾燥器

(1) 連小 (2) B (3) B (4) C (7) $30 \mathrm{sec}$ $\sim 5 \mathrm{~min}$ (9) テンター乾燥器に熱風と併用で使 用される

\section{X. 塗料, 塗布液}

a. 赤外線乾燥器

（1）連大特よび小，回小（2）A （3）B （4） C (7) 2 10 min (長くて $30 \mathrm{~min}$ ) (8) 複雑 な形のるのは不適。（9）熟風と併用されること が多い。輻射強度 $2000 \sim 7000 \mathrm{kcal} / \mathrm{hr} \mathrm{m}^{2}$

b. 並行流または直角流トンネル（箱型）乾燥器
(1) 連大扎よび小
(2) $\mathrm{A}$
(3) $\mathrm{A}$
(4) $\mathrm{C}$
(7) 1〜10 min 他はIX a. K同じ 